\title{
Recurrent Malignant Glioma
}

National Cancer Institute

\section{Source}

National Cancer Institute. Recurrent Malignant Glioma. NCI Thesaurus. Code C142848.

The reemergence of malignant glioma after a period of remission. 